\title{
Consumer's characteristics of yogurt in Manado, North Sulawesi - Indonesia
}

\author{
E. Wantasen, F. H. Elly and N.M. Santa \\ Faculty of Animal Husbandry, Sam Ratulangi University, \\ Jalan Kampus - Bahu, Manado 95115 - Indonesia \\ Corresponding E-mail: erwin wantasen@yahoo.co.id
}

Received April 14, 2016; Accepted January 06, 2017

\begin{abstract}
ABSTRAK
Tujuan penelitian ini adalah mengetahui karakteristik konsumen, kepuasan konsumen dan faktor yang mempengaruhi keputusan konsumen membeli yogurt di Kota Manado, Provinsi Sulawesi Utara. Data primer diperoleh dari 400 responden konsumen di Kota Manado dengan menggunakan daftar pertanyaan berstruktur. Penentuan sampel responden dilakukan dengan metode accidental sampling. Pengumpulan data dilakukan sejak bulan Juli sampai September 2015. Analisis data penelitian dilakukan secara deskriptif dan analisis kuantitatif menggunakan analisis Importance-performance analysis (IPA), Consumer Satisfaction Index (CSI) dan analisis faktor. Hasil penelitian menunjukkan bahwa sebagian besar konsumen adalah pelajar wanita, belum menikah, yang berusia antara 14-19 tahun. Sebagian besar diantara mereka adalah lulusan sekolah menengah atas dan sedang melanjutkan studi di universitas. Konsumen di Kota Manado berada dalam kategori cukup puas terhadap keberadaan produk yogurt yang dijual di pasaran. Atribut kandungan bahan pengawet dan ketersediaan produk dimana saja adalah dua atribut penting yang perlu ditingkatkan oleh produsen untuk meningkatkan kepuasan konsumen. Secara parsial variabel bebas yang mempengaruhi keputusan konsumen untuk membeli yogurt adalah faktor kandungan bahan pengawet, produk tersedia dimana saja, variasi rasa, nilai gizi dan volume produk.

Kata kunci : karakteristik konsumen, yogurt, konsumsi
\end{abstract}

\begin{abstract}
The objective of this study was to analyze consumer's characteristics of yogurt as one of fermented dairy product, consumers satisfaction and factors influencing consumers purchase decision on yogurt in Manado city. The primary data were collected using structured questionnaire from a total sample of 400 consumers in Manado City. Samples were selected using the accidental sampling method with schedule (using alternating date/ day and place, respectively). Collecting data were done from July to September 2015. The result indicated that most consumers were teenagers, female students, and single persons. Consumers of yogurt in Manado City are were categorized quite satisfied with yogurt product. The product availability had to be considered by producer in order to increase consumer satisfaction. Partially, factors that significantly influencing consumer's purchase decision in Manado were preservative content, product availability, variant flavor, product volume and additional nutritive value.

Keywords: consumers characteristics, yogurt, consumption
\end{abstract}




\section{INTRODUCTION}

Processed milk such as yogurt has become famous and attractive food nowadays (Pomsanam, et al., 2014; Davis, et al., 2010). Increased urbanization and income growth in developing countries are some factors that cause the increase in consumption of more expensive food, such as milk and milk product included yogurt. The advantage of yogurt as one of the functional food is scientifically recognized as having physiological benefits beyond those of basic nutrition to human health, and this is also giving a reason why it tend to becomes popular today (Weerathilake et al., 2014; McKinley, 2005; Murphy et al., 2015; Pohijanheimo and Sandell, 2009). Microbe is the main component to produce yogurt by fermenting process (Sfakianasis and Constatnina, 2014). Many yogurt stores offered various type of yogurt such as frozen yogurt and drinking yogurt in various flavors.

Wright and Meylinah (2014) stated that most Indonesian cows located in Java provides largest contribution towards milk product in 2013. Wright and Meylinah (2014) reported that more than 60\% of the milk produced in Indonesia is sold as raw material by the major milk processing industries and remaining $20 \%$ is sold direct by KUDs to consumers in Indonesia as fresh liquid milk or yogurt drinks (Wright and Meylinah, 2014). Manado city is one of potential market area for dairy product such as yogurt because it the population is approximately 432.139 in 2014 (Biro Pusat Statistik Sulawesi Utara, 2015). Yogurt store in Manado city was increased by 35\% in 2015 (Biro Pusat Statistik Sulawesi Utara, 2015). The data indicated there was increasing of yogurt consumption in Manado. Nevertheless, market share of yogurt in Manado was 23.67\%, while milk powder and condensed milk as competitors still dominated the market share of dairy product in Manado with $57.84 \%$. This It is because consumers in Manado considered yogurt as relatively new type of dairy product than milk powder and condensed milk. Several brands of yogurt marketed in Manado are heavenly blush, cimory, yummy, elle and vire. All of those milk products promote health as a main element to attract consumers but producers of milk powder and condensed milk continuously increase innovation on their product to retain their consumer loyalty. If yogurt manufactures do not maximized performances and attributs of their product, market share of yogurt may decrease in the future. Product innovation and development by competitors could be a threat and affect consumers satisfaction, and this my influences the sales volume. Consumer characteristics may help to explain how consumers obtain satisfaction and become loyal to the product. Therefore, information about consumer characteristics and satisfaction of yogurt is needed to make the right decision in marketing yogurt in Manado. Based on this background, the aims of this research was to search consumers characteristics of yogurt and their satisfaction, and to study factors affecting consumers decision to purchase yogurt in Manado City.

\section{MATERIALS AND METHODS}

\section{Sampling Methods and Data Collection}

The study was conducted in Manado as capital of Noth Sulawesi Province which has potensial population and good income distribution. Population that could be consumer of yogurt in Manado City was 432,139 people where 325,115 people was live in urban area, and another 107,024 people was in sub urban area both male and female with age ranging from 15 to 60 years (Biro Pusat Statistik Kota Manado, 2015). This study used 400 sample of consumers calculated by formula of Knottnerus (2003):

$$
\mathrm{n}=\frac{\mathrm{N}}{\mathrm{N}(\mathrm{d})^{2}+1}
$$

where

$$
\begin{array}{ll}
\mathrm{n} & : \text { Size of sample } \\
\mathrm{N} & : \text { Size of population } \\
\mathrm{d} & : \text { Margin of error }(5 \%)
\end{array}
$$

Distribution of respondents was determined using proportional sampling according to the number of population in urban and sub urban area. The total of respondent in urban area was 300 respondents consisted of 243 respondents as buyers and 57 respondents non buyers while in sub urban area was 100 respondents consisted of 47 respondents as buyers and 53 respondents non buyers. Therefore number of buyers were 290 whereas non buyers were 110 respondents. Non buyer respondents was selected to get information about their reason for not purchasing yogurt product. All targeted respondents were selected by accidental sampling method with schedule (using alternating date/day and place) respectively. Research was conducted in three supermarkets and one traditional market in the urban area, two 
supermarkets in the sub urban area. All supermarkets and traditional markets were huge and complete in Manado city, located in strategic places so it is easy to be accessed by consumers. Primary data were collected using questionnaire included demographic information, consumer behavior, and factors influence purchase decision by consumers of yogurt. Secondary data were collected from relevant academic studies such as: textbooks, online articles and websites as well as related research reports.

\section{Data Analysis}

Data were analyzed by using descriptive and quantitative methods. Descriptive analysis described characteristic of the respondents whereas quantitative analysis determined respondents satisfaction and factors influencing decision to purchase yogurt. ImportancePerformance analysis (IPA) and analysis of consumer satisfaction index (CSI) were used to measure consumers satisfaction toward level of importance and performance of product attributes (Supranto, 2001). The questionnaire was made from scale 1 (not important/not good) to 5 (very important/very good). Mean score level of importance and performance attributes were predicted by formula as follows:

$$
\bar{X}=\frac{\sum X_{i}}{n} \quad \bar{Y}=\frac{\sum Y_{i}}{n}
$$

Where:

$\overline{\mathrm{X}}=$ Mean score of importance level for $\mathrm{i}^{\mathrm{th}}$ attribute of yogurt

$\overline{\mathrm{Y}}=$ Mean score of performance level for $\mathrm{i}^{\text {th }}$ attribute of yogurt

$\mathrm{n}=$ the number of respondents

The attribute evaluated by respondent include variant flavor, specific flavor, attractive packaging, viscosity, additional nutritive value, preservatives content, safety package, pricevolume ratio, legal/halal assurance and product licenses, expired date availability, product availability and product volume. Consumer satisfaction index was measured by using criteria of consumer satisfaction as follows :

\begin{tabular}{cl}
\hline Range of Scale & \multicolumn{1}{c}{ Interpretation } \\
\hline $0.00-0.20$ & Very Disappointed \\
$0.21-0.40$ & Disappointed \\
$0.41-0.60$ & Quite Satisfied \\
$0.61-0.80$ & Satisfied \\
$0.81-1.00$ & Very Satisfied \\
\hline
\end{tabular}

One of the procedures to extract data in analysis of factor is principal component analysis (Malhotra, 1996). Factors affecting consumer decision to purchase yogurt was evaluate by using analysis of factor (Malhotra, 1996). Variables measured were product quality (additional nutritive value, viscosity, attractive packaging), taste (variant flavor, specific flavor), promotion (price and volume ratio, product volume, can be consumed everytime), product safety (safety package, preservative content, expired date availability, legal/"halal" assurance and product license), place (product availability). Mathematically model of the analysis was performed according to Gujarati (1978):

$\mathrm{Z}=\alpha 0+\alpha 1 \mathrm{Q}_{1}+\alpha 2 \mathrm{Q}_{2}+\alpha 3 \mathrm{Q}_{3}+\alpha 4 \mathrm{Q}_{4}+\alpha 5 \mathrm{Q}_{5}+\mathrm{ei}$ where:

$$
\begin{array}{ll}
\mathrm{Z} & : \text { Purchase decision } \\
\alpha \mathrm{O} & : \text { Constant } \\
\alpha 1, \alpha 2, \ldots \alpha 5: \text { coefficient } \\
\mathrm{Q}_{1} & : \text { Product quality consist of } \mathrm{Q}_{1.1^{-}} \\
& \mathrm{X}_{1.3} \\
\mathrm{Q}_{2} & : \text { Taste, consist of } \mathrm{Q}_{2.1}-\mathrm{Q}_{2.2} \\
\mathrm{Q}_{3} & : \text { Promotion consist of } \mathrm{Q}_{3.1}-\mathrm{Q}_{3.3} \\
\mathrm{Q}_{4} & : \text { Product Safety consist of } \mathrm{Q}_{4.1^{-}} \\
& \mathrm{Q}_{4.4} \\
\mathrm{Q}_{5} & : \text { Place consist of } \mathrm{Q}_{5.1} \\
\mathrm{e}_{\mathrm{i}} & : \text { Error term }
\end{array}
$$

All variables $\left(\mathrm{Z}, \mathrm{Q}_{1}, \mathrm{Q}_{2}, \mathrm{Q}_{3}, \mathrm{Q}_{4}, \mathrm{Q}_{5}\right)$ were measured using interval scale 1-5 with agreed/disagreed scale technique (Sekaran and Bougie, 2013). To estimate the coefficient of regression, ordinary least square method was used.. Furthermore, the accuracy of the model was evaluated using $\mathrm{R}^{2}$, $\mathrm{F}$ test and $\mathrm{t}$ test (Gujarati, 1978) Completion analysis was conducted using computer with SPSS version 18.0

\section{RESULTS AND DISCUSSION}

\section{Characteristics of Respondents}

Table 1 indicates that generally yogurt's consumers in Manado were female, teenagers, single and most of them were students. This indicated that more females are aware of their health than male consumers do. Most of them consume yogurt in order to keep healthy and control their diet. The result was in parallel with Verbeke (2005) who found that most consumers were female. The ages of respondents in the urban area were teenagers $(46.9 \%)$ with an average of 
Table 1. Characteristics of Respondents

\begin{tabular}{|c|c|c|c|c|c|}
\hline \multirow[b]{2}{*}{$\begin{array}{c}\text { Characteristics of } \\
\text { Respondent }\end{array}$} & \multicolumn{2}{|c|}{ Urban Area } & \multicolumn{2}{|c|}{ Sub Urban Area } & \multirow{2}{*}{$\begin{array}{c}\text { Urban+Sub } \\
\text { Urban } \\
\text { Buyer and Non } \\
\text { Buyer } \\
(\mathrm{n}=400)\end{array}$} \\
\hline & $\begin{array}{l}\text { Buyers } \\
(n=243)\end{array}$ & $\begin{array}{c}\text { Non } \\
\text { Buyers } \\
(\mathrm{n}=57)\end{array}$ & $\begin{array}{l}\text { Buyers } \\
(n=47)\end{array}$ & $\begin{array}{c}\text { Non } \\
\text { Buyers } \\
(\mathrm{n}=53)\end{array}$ & \\
\hline & & 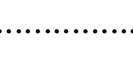 & $\%$. & ......... & .......... \\
\hline \multicolumn{6}{|l|}{ Sex } \\
\hline Male & 25.5 & 49.1 & 38.3 & 43.4 & 32.7 \\
\hline Female & 74.5 & 50.9 & 61.7 & 56.6 & 67.3 \\
\hline \multicolumn{6}{|l|}{ Age (years) } \\
\hline $14-19$ & 46.9 & 18.18 & 17.5 & 18.33 & 36.0 \\
\hline $20-24$ & 36.3 & 31.8 & 15.0 & 25.0 & 32.0 \\
\hline $25-29$ & 11.71 & 11.3 & 25.0 & 13.3 & 13.2 \\
\hline $30-34$ & 3.12 & 13.6 & 22.5 & 11.7 & 7.5 \\
\hline $35-39$ & 1.56 & 11.6 & 12.5 & 13.3 & 5.5 \\
\hline$\geq 40$ & 1.17 & 13.6 & 7.5 & 18.3 & 5.75 \\
\hline \multicolumn{6}{|l|}{ Marital status } \\
\hline Single & 76.5 & 57.8 & 40.2 & 37.7 & 64.5 \\
\hline Married & 23.4 & 42.1 & 59.5 & 62.2 & 35.5 \\
\hline \multicolumn{6}{|l|}{ Income (IDR/Month) } \\
\hline$\leq 500,000$ & 12.6 & 14.5 & 10.8 & 24.8 & 13.0 \\
\hline$>500,000-\leq 1,000,000$ & 50.6 & 32.7 & 13.0 & 18.5 & 39.5 \\
\hline$>1,000,000-\leq 1,500,000$ & 12.2 & 16.3 & 17.3 & 22.2 & 14.7 \\
\hline$>1,500,000-\leq 2,000,000$ & 7.75 & 14.5 & 21.7 & 25.9 & 12.7 \\
\hline$>2,000,000-\leq 2,500,000$ & 6.93 & 18.1 & 28.2 & 12.9 & 11.7 \\
\hline$>2,500,000$ & 9.8 & 3.6 & 8.7 & 5.5 & 8.3 \\
\hline \multicolumn{6}{|l|}{ Occupation } \\
\hline Student & 73.8 & 52.5 & 21.2 & 28.3 & 59.5 \\
\hline Public Sector & 3.5 & 15.0 & 23.4 & 20.8 & 9.2 \\
\hline Private Sector & 11.9 & 20.0 & 27.6 & 26.4 & 16.5 \\
\hline Self Employed & 7.7 & 7.5 & 17 & 18.8 & 10.2 \\
\hline Housewife & 3.1 & 5.0 & 10.6 & 5.6 & 4.5 \\
\hline \multicolumn{6}{|l|}{ Level of education } \\
\hline 9 Years & 6.2 & 7.0 & 14.9 & 18.9 & 9.0 \\
\hline 12 Years & 69.9 & 49.1 & 29.8 & 37.7 & 58.0 \\
\hline 15 Years & 9.5 & 13.0 & 23.4 & 26.4 & 13.8 \\
\hline 16 Years & 14.4 & 31.6 & 31.9 & 16.9 & 19.3 \\
\hline
\end{tabular}


18.3 years old whereas in the sub urban area were $20-24$ years old $(15 \%)$ with an average of 23.5 years old. It was clear that teenagers dominated urban yogurt market while middle-aged consumers dominated in the sub-urban area. This finding was related to the location of yogurt store in urban areas where mostly are located near educative institutions (Sam Ratulangi University, UNPI, STIEPAR, High School). Therefore, the target consumers were teenagers or students. The result was in line with Verbeke (2005) who found that consumers with less than 25 years old dominated behaviors toward yogurt in Belgium and Poland.

Furthermore, with regard of academic educational level, the study reveals that there was a slight tendency in urban area that consumers with academic education had intention to purchase yogurt. More than half of the urban consumers were graduated from senior high school and still study in universities $(69.95 \%)$ while most of sub-urban consumers were universities graduates $(31.91 \%)$. This was related to the location of yogurt store where mostly near and/or close to universities or colleges, while location of yogurt stores in sub-urban area were spread in residential and office areas. Therefore, most of urban consumers were students (73.84\%), whereas most of sub-urban consumers were workers and private officials $(27.65 \%)$. These results were in line with Widiati et al. (2013), education background and school location were highly significant factors in determining milk consumption expenditure of consumers in Yogyakarta Province.

In terms of consumers income level, there were differences between those two areas due to their differences in occupation where the urban were dominated by students while the sub urban were dominated by private sector officers. Most urban consumers earned income level ranging between $>$ IDR 500,000 - $\leq 1,000,000$ (approximately IDR 13,475 = 1 USD) per month (50.61\%), while most sub urban consumers earned income level ranging between > IDR $2,000,000$ - $\leq$ IDR 2,500,000 per month (28.26\%). This can be explained in detailed that more than half of the buyers in urban areas were students who didn't have their own monthly salary but they got income from their parents so the decision to buy yogurt was highly influenced by their parents also their surrounding environment (friends) or just for their own lifestyle. Yakup and Jablonski (2012) stated that consumer purchase behavior was affected by family, economic situation and their lifestyle.

\section{Distribution of Consumers Evaluation on Importance and Performance Level of Yogurt's Attributes}

Result of study showed that variety of flavor was the most important attribute for yogurt (82\%). At the level of performance, 76 percent of consumers declared that this attribute was good. Other attributes are shown in Table 2.

\section{Importance and Performance Analysis}

Table 3 shows that preservatives content was considered as the most importance attribute of yogurt. This was related to healthy reason, so that consumers assume more preservatives may impact on their health condition. The second rate was safety package. Consumer considered packaging condition may affect the quality of the product, such as freshness of yogurt. Other findings showed that price has not become very important attribute of yogurt. Feeling satisfied when consume yogurt is more important to consumers in Manado than the price they have to pay.

Attribute rating of yogurt based on its performance are presented in Table 4. The result showed that the most important performance of yogurt attributes was safety package when consumed. Consumers assumed that this attribute may determine the quality of yogurt especially its nutritive value. The second one was additional nutritive value. This attribute related to healthy reason where consumer preferred product that provided more additional nutritive value. This means that consumers in Manado more concerned with the attributes performance of yogurt that impact on health compared to physical appearance of the product. The study was in line with Johansen et al. (2011), health information and perception were crucial to consumers' ability to make informed food choices. Additionally, they also informed that nutritional information was expected to influence consumer perceptions and acceptance of health-improved food. Messina et al. (2008) stated that specific ingredients in functional food (i.e., probiotic) which were likely to deliver health benefits were now generally more accepted by consumers. Study conducted by Oakes and Slotterback (2001) showed that food choice motives related to improve health or to lose weight tended to influence their perceptions. 
Table 2. Distribution of Consumers Evaluation on Importance and Performance Level of Yogurt's Attributes $(\mathrm{n}=290)$

\begin{tabular}{|c|c|c|c|c|c|c|c|c|c|c|}
\hline \multirow[t]{2}{*}{ Attributes } & \multicolumn{5}{|c|}{$\begin{array}{l}\text { Level of Performance } \\
\qquad(\mathrm{n}=290)\end{array}$} & \multicolumn{5}{|c|}{$\begin{array}{l}\text { Level of Importance } \\
\qquad(n=290)\end{array}$} \\
\hline & $\mathrm{W}$ & $\mathrm{P}$ & $\mathrm{F}$ & $\mathrm{G}$ & VG & $\mathrm{VU}$ & UI & QI & I & VI \\
\hline Variety of flavor & 3 & 67 & 185 & 35 & 0 & 14 & 38 & 174 & 64 & 0 \\
\hline Specific flavor & 17 & 49 & 177 & 43 & 3 & 9 & 38 & 171 & 72 & 0 \\
\hline Attractive of packaging & 0 & 72 & 186 & 32 & 0 & 20 & 107 & 26 & 136 & 0 \\
\hline Viscosity of yogurt & 0 & 12 & 218 & 41 & 20 & 6 & 0 & 96 & 168 & 20 \\
\hline Additional nutritive value & 0 & 11 & 183 & 87 & 9 & 3 & 9 & 116 & 148 & 14 \\
\hline Preservatives content & 0 & 49 & 203 & 35 & 3 & 0 & 9 & 49 & 232 & 0 \\
\hline Safety package & 0 & 20 & 160 & 96 & 14 & 0 & 9 & 87 & 168 & 26 \\
\hline $\begin{array}{l}\text { Can be consumed } \\
\text { everytime }\end{array}$ & 0 & 20 & 188 & 81 & 0 & 9 & 29 & 128 & 125 & 0 \\
\hline Price volume ratio & 0 & 72 & 186 & 32 & 0 & 12 & 64 & 180 & 32 & 3 \\
\hline $\begin{array}{l}\text { Legal/halal assurance and } \\
\text { product license }\end{array}$ & 3 & 14 & 212 & 55 & 6 & 0 & 14 & 142 & 125 & 9 \\
\hline Expired date availability & 0 & 40 & 212 & 29 & 9 & 9 & 38 & 177 & 61 & 6 \\
\hline Product availability & 0 & 43 & 194 & 38 & 14 & 3 & 32 & 110 & 136 & 9 \\
\hline Product volume & 0 & 11 & 217 & 41 & 20 & 0 & 12 & 130 & 148 & 0 \\
\hline
\end{tabular}

$\mathrm{W}=$ Worst; $\mathrm{P}=$ Poor; F = Fair; G = Good; VG = Very Good; VU = Very Unimportant; UI = Unimportant; QI $=$ Quite Important; I = Important; VI = Very Important

Table 3. Attribute Rating of Yogurt Based on Level of Importance

\begin{tabular}{lcc}
\hline Attributes & $\begin{array}{c}\text { Mean Score } \\
\text { of } \\
\text { Importance } \\
\text { Level }\end{array}$ & Rank \\
\hline Preservatives content & 3.780 & 1 \\
Safety package & 3.740 & 2 \\
Viscosity of yogurt & 3.690 & 3 \\
Nutritional value & 3.570 & 4 \\
Product volume & 3.480 & 5 \\
Legal/halal assurance and & 3.460 & 6 \\
product license & 3.410 & 7 \\
Product availability & 3.360 & 8 \\
Can be consumed everytime & 3.160 & 9 \\
Specific flavor & 3.050 & 10 \\
Expired date availability & 2.980 & 11 \\
Variety of flavor & 2.950 & 12 \\
Attractive of packaging & 2.750 & 13 \\
Price and volume ratio & &
\end{tabular}

Table 4. Attribute Rating of Yogurt Based on Level of Performance

\begin{tabular}{lcc}
\hline Attributes & $\begin{array}{c}\text { Mean Score } \\
\text { of } \\
\text { Performance } \\
\text { Level }\end{array}$ & Rank \\
\hline Safety package & 3.350 & 1 \\
Additional nutritive value & 3.310 & 2 \\
Product volume & 3.240 & 3 \\
Viscosity of product & 3.230 & 4 \\
Can be consumed everytime & 3.200 & 5 \\
Legal/Halal assurance and & 3.160 & 6 \\
product license & & \\
Product availability & 3.070 & 7 \\
Expired date availibility & 3.020 & 8 \\
Preservative content & 2.980 & 9 \\
Specific flavor & 2.870 & 10 \\
Variety of flavor & 2.850 & 11 \\
Price and volume ratio & 2.830 & 12 \\
Attractive of packaging & 2.820 & 13 \\
\hline
\end{tabular}




\section{Consumer Satisfaction Index (CSI)}

The results showed that total weighted score of all attribute in yogurt was 3.024 (Table 5). Consumer satisfaction index (CSI) was obtained by dividing total weighted score with five as maximum scale used in this study. Hence CSI value is 0.6048 or 60.48 percent. The index was in range 0.41- 0.60 therefore consumers of yogurt in Manado City are categorized quite satisfied. The result indicated that producers of yogurt must continue to improve their attribute performance in order to increase customer satisfaction. There are two attributes that have high importance rate but the performance was relatively low namely preservative content and product availability. Both attributes must be priority to improve by the producer in order to increase customers satisfaction.

\section{Factors Influencing Purchase Decision}

There ware five factors having an impact on purchase intention. Based on principal component analysis showed that all of the variables have value more than 0.4 . Hence those variables could be considered by consumers to purchase yogurt (Table 6). The result of regression analysis from
290 respondents as buyers are presented in Table 7. The dependent variables have affected consumer's purchase decision on yogurt as much as $79.4 \%\left(\mathrm{R}^{2}=0.794\right)$. Partially, the variables that significantly $(\mathrm{P}<0.01)$ had positive effect on consumer's purchase decision were variety of flavor (0.891) and product volume (0.826), while additional nutritive value $(0.568)$, preservative content $(0.527)$ and product availability $(0.558)$ had positive influence $(\mathrm{P}<0.05)$ to purchase decision of yogurt by consumers. The result was in line with previous study of Amarukachoke (2015) and Kusumastuti et al. (2013) that factors such as product availability, high quality product, nutrition knowledge, health motivation, benefit from product, variation of flavor, lifestyle had a significant influence for consumer to purchase milk and yogurt. A study of Urala and Lahteenmaki (2003) indicated that taste and sensory quality were the reason mentioned the most for choosing yogurt, ice cream juice and sweets.

\section{Reason for Not Purchasing Yogurt}

The respondents who declared as non-buyer were asked about their reason for not purchasing

Table 5. Consumer Satisfaction Index (CSI) of Yogurt In Manado

\begin{tabular}{lcccc}
\hline \multicolumn{1}{c}{ Attributes } & $\begin{array}{c}\text { Mean Score of } \\
\text { Importance } \\
\text { (MSI) }\end{array}$ & $\begin{array}{c}\text { Weighted } \\
\text { Factor } \\
\text { (WF=MSI/ } \\
43.38)\end{array}$ & $\begin{array}{c}\text { Mean Score } \\
\text { of } \\
\text { Performance } \\
\text { (MSP) }\end{array}$ & $\begin{array}{c}\text { Total Weighted } \\
\text { Score } \\
\text { (WS =MSP X } \\
\text { WF) }\end{array}$ \\
\hline Preservatives content & 3.780 & 0.087 & 2.980 & 0.259 \\
Safety package & 3.740 & 0.086 & 3.350 & 0.288 \\
Viscosity of yogurt & 3.690 & 0.085 & 3.230 & 0.274 \\
Additional nutritive value & 3.570 & 0.082 & 3.310 & 0.271 \\
Product volume & 3.480 & 0.080 & 3.240 & 0.259 \\
Legal assurance and product license & 3.460 & 0.079 & 3.160 & 0.249 \\
Product availability & 3.410 & 0.078 & 3.070 & 0.239 \\
Can be consumed everytime & 3.360 & 0.077 & 3.200 & 0.246 \\
Specific flavor & 3.160 & 0.072 & 2.870 & 0.206 \\
Expired date availability & 3.050 & 0.070 & 3.020 & 0.211 \\
Variety of flavor & 2.980 & 0.068 & 2.850 & 0.193 \\
Attractive of packaging & 2.950 & 0.068 & 2.820 & 0.191 \\
Price and volume ratio & 2.750 & 0.063 & 2.830 & 0.172 \\
\hline Total & 43.380 & 1.000 & 39.90 & 3.024 \\
\hline CSI = (TWS : 5) X 100\% & & & & 60.48 \\
\hline
\end{tabular}

CSI $=$ Consumer Satisfaction Index $;$ TWS $=$ Total Weighted Score 
Table 6. Factor Analysis

\begin{tabular}{|c|c|c|c|c|c|}
\hline \multirow{2}{*}{ Variables } & \multicolumn{5}{|c|}{ Factor Loading } \\
\hline & 1 & 2 & 3 & 4 & 5 \\
\hline \multicolumn{6}{|l|}{ Product Quality } \\
\hline Viscosity & 0.583 & & & & \\
\hline Attractive packaging & 0.492 & & & & \\
\hline Additional nutritive value & 0.795 & & & & \\
\hline \multicolumn{6}{|l|}{ Taste } \\
\hline Variety of flavor & & 0.887 & & & \\
\hline Specific flavor & & 0.763 & & & \\
\hline \multicolumn{6}{|l|}{ Promotion } \\
\hline Can be consummed everytime & & & 0.667 & & \\
\hline Price and volume ratio & & & 0.785 & & \\
\hline Product volume & & & 0.865 & & \\
\hline \multicolumn{6}{|l|}{ Product Safety } \\
\hline Safety package & & & & 0.723 & \\
\hline Preservative content & & & & 0.969 & \\
\hline Expired date availability & & & & 0.735 & \\
\hline Legal/Halal assurance and product license & & & & 0.705 & \\
\hline \multicolumn{6}{|l|}{ Place } \\
\hline Product availability & & & & & 0.864 \\
\hline
\end{tabular}

Table 7. Factor Influencing Purchase decision

\begin{tabular}{llll}
\hline \multicolumn{1}{c}{ Variables } & Coefficients & \multicolumn{1}{c}{ t- Statistic } & Probability \\
\hline Constant & 2.482 & $2.927 * * *$ & 0.003 \\
Additional nutritive value $\left(\mathrm{Q}_{1.3}\right)$ & 0.568 & $2.179^{* *}$ & 0.038 \\
Variety of flavor $\left(\mathrm{Q}_{2.1}\right)$ & 0.891 & $7.206^{* * *}$ & 0.000 \\
Product volume $\left(\mathrm{Q}_{3.3}\right)$ & 0.826 & $5.113^{* * *}$ & 0.006 \\
Preservative content $\left(\mathrm{Q}_{4.2}\right)$ & 0.527 & $2.227 * *$ & 0.032 \\
Product availability $\left(\mathrm{Q}_{5.1}\right)$ & 0.558 & $2.049^{* *}$ & 0.041 \\
Adjusted $\mathrm{R}^{2}$ & 0.794 & & \\
F-value & 0.000 & & \\
\hline
\end{tabular}

$* * *=$ Level significantly of $0.01(\mathrm{P}<0.01)$

$* *=$ Level significantly of $0.05(\mathrm{P}<0.05)$

yogurt. Table 8 shows that the main reason of urban consumers not to purchase yogurt was due to the expensive price of its product (35.08\%). In Manado city, the price of yogurt is almost 3-4 times higher than milk or fresh milk. Therefore, nearly $14.03 \%$ of non buyer in urban area preferred to consume milk than yogurt. Overall, the main reason for the majority of the non buyers in both urban and sub urban areas in Manado were unfamiliarity (37.27\%), its expensiveness $(26.36 \%)$ and its unfavorable taste (13.63\%). 
Table 8. Reason for Not Purchasing Yogurt in Urban and Sub-Urban areas of Manado City, North Sulawesi Province $(\mathrm{n}=110)$

\begin{tabular}{|c|c|c|c|c|c|c|}
\hline \multirow{2}{*}{ Reason for not to purchase } & \multicolumn{2}{|c|}{ Urban } & \multicolumn{2}{|c|}{ Sub Urban } & \multicolumn{2}{|c|}{ Total } \\
\hline & $\mathrm{n}=57$ & $\%$ & $\mathrm{n}=53$ & $\%$ & $\mathrm{n}=110$ & $\%$ \\
\hline Too expensive & 20 & 35.08 & 9 & 16.98 & 29 & 26.36 \\
\hline Not effective & 3 & 5.26 & 3 & 5.67 & 6 & 5.45 \\
\hline Unfavorable taste & 9 & 15.78 & 6 & 11.32 & 15 & 13.63 \\
\hline Unfamiliarity & 17 & 29.82 & 24 & 45.28 & 41 & 37.27 \\
\hline Prefer drink fresh milk than yogurt & 8 & 14.03 & 11 & 20.75 & 19 & 17.27 \\
\hline
\end{tabular}

\section{CONCLUSION}

Preservative content, product availability, variant flavor, product volume and additional nutritive value determined purchase decision of yogurt by consumers in Manado. Preservative content and product availability were attributes that must be improved by producer in order to increase consumer satisfaction

\section{REFFERENCES}

Amarukachoke, T. 2015. Factors Influencing Purchase Intention Toward Cup Yogurt. Independent Study Manuscript. Graduate School of Bangkok University

Biro Pusat Statistik Sulawesi Utara. 2015. Sulawesi Utara Dalam Angka. Manado. Sulawesi Utara

Biro Pusat Statistik Kota Manado. 2015. Manado Dalam Angka. Manado. Sulawesi Utara

Davis, C., D. Blayney, A. Muhammad, T.Y. Steven and J. Cooper. 2010. A crosssectional analysis of U.S Yogurt demand. J. Food Disribution Res. 41(2): 36-45.

Gujarati, D. N. 1978. Basic Econometrics. McGraw-Hill Book Co. Inc. New York

Johansen, S.B., T. Naes and M . Hersleth. 2011. Motivation for choice and healtiness perception of calorie-reduced dairy products. A. cross cultural study. J. Appetite. 56:15-24.

Knottnerus, P. 2003. Sample Survey Theory: Some Pythagorean Perspectives. Springer Science Business Media New York

Mckinley, M.C. 2005. The nutrition and health benefits of yoghurt. Int. J. Dairy Technol. 58 (1): $1-12$

Messina, F., A. Saba and A. Turrini. 2008. Older people's perception toward conventional and functional yogurt through repertory grid method. A cross country study. Br. Food. J. 110:790-804.

Kusumastuti, A.E., A. Nissapa, B.A. Nugroho and P. Phittayaphinanth. 2013. Consumer's perceptions towards yogurt: A case study in Malang city, East Java Province, Indonesia. J.Agric.Technol. 9:1125-1136.

Malhotra, N. K. 1996. Marketing Research And Applied Orientation. Prentice Hall.Inc, New Jersey.

Murphy, M.M., L.M. Barraj, L.D. Toth, L.S. Harkness and D.R. Bolster. 2015. Daily intake of dairy product in Brazil and contribution to nutrient intakes: a crosssectional study. Public Health Nutr. 19(3): 393-400

Oakes, M.E and C.S. Slotterback. 2001. Judgement of food healthfulness food name stereotypes in adults over age 25. J. Appetite $37: 1-8$.

Pohijanheimo, T. and M. Sandell. 2009. Explaining the liking for drinking yogurt: the role of sensory quality, food choice motives, health concern and product information. Int. Dairy J. 19:459-466.

Pomsanam, P., K. Napompech and S. Suwanmaneepong. 2014. Factors driving Thai consumers' intention to purchase organic food. Asean J. Sci. Res.. 7(4): 434446

Sekaran, U. and R. Bougie. 2013. Research 
Methods for Business: A skill Building Approach. $6^{\text {th }}$ Ed. John Wiley \& Sons, Inc.

Sfakianasis, P. and T. Constatnina. 2014. Conventional and innovative processing of milk for yogurt manufacture ; development of texture and flavor: a review. Foods. 3(1): 176-193.

Supranto, J. 2001. Pengukuran Tingkat Kepuasan Pelanggan untuk Menaikkan Pangsa Pasar. Rineka Cipta. Jakarta

Urala, N. and L. Lahteenmaki. 2003. Reason behind consumer's functional food choices. J. Nutr. Food Sci. 33: 148-158

Verbeke, W. 2005. Consumers acceptance on functional foods: Socio-demographic cognitive and attitudinal determinats. Food Quality and Preference 13: 45-57.

Weerathilake, W. A. D. V., D. M. D. Rasika, J. K.
U. Ruwanmali and M. A. D. D. Munasinghe. 2014. The evolution, processing, varieties and health benefits of yogurt. Int. J. Sci. Res. Publ. 4 (4): 1-10.

Widiati, R., T.A. Kusumastuti and S. Andarwati. 2013. Milk consumption behavior in household having children in growing age in Yogyakarta Special Province. J. Indonesian. Trop. Anim. Agric. 38 :225-232.

Wright, T. and S. Meylinah. 2014. Indonesia Dairy and Products Annual Reports 2014. GAIN Report. USDA Foreign Agriculture Service.

Yakup, D and S. Jablonski. 2012. Integrated approach to factors affecting consumers purchase behavior in Poland and an empirical study. Global J.Management and Business Res. 12: 61-87. 